$448(530)$

\title{
$P-515$ BBNラット膀胱発癌におけるBCG膀胱内注入㞠法の効果
}

\author{
名古屋市立大学 \\ 秋田英俊, 岡村武彦, 伊藤恭典, 浅井伸章, 山田泰之, 戸澤啓一, 上田公介, , \\ 郡 健二郎
}

【目的】ヒト表在性膀胱腫湯に対するBCG膀腅内注入療法は臨床的にほほ確立された治療法であるが, 無効例も多く，確実な治療法が望まれている。また，これに対する十分な実験モデルも確泣されていな いのが現状である。そこで, ラットにBBNを投与し，発生した膀胱腫滾および前癌病変に対してBCGの 膀胱内注入を行いその効果を検討した。【方法】84匹のF344膗ラットを6群に分けて実験行った。1 群から 5 群までは $0.05 \% \mathrm{BBN} 10$ 週間飲料水として投与した。1 群はBBN投与のみのコントロール群。 2 群は $0.3 \mathrm{ml}$ のBCG $(2 \mathrm{mg} / 1 \mathrm{ml}$ 生理食塩水) を週 1 回, BBN投与終了 1 週間後より合計 6 回膀胱内注入 を行った。 3 群はBCGの代わりに0.3m1の生理食塩水を 2 群と同様似投与した。 4 群はBBN投与終了 15 週間後より同量のBCGを週 1 回, 合計 6 回膀腅内注入を行った。 5 群はBCGの代わりに同量の生理食塩 水を 4 群と同様に投与した。6 群はBBNを投与せず，4 群と同時期に同量のBCGを週 1 回，合計 6 回膀 胱内注入を行った。全ての動物は実験開始後32週で屠殺した。【結果と考察】肉眼的には, 生理食塩水 の膀胱内注入はいずれの投与時期においても膀胱腫場および前癌病変に対してプロモーション作用を示 した。病理組軄学的には，BCGを早期（予防的）に投与した群（2群）において膀胱癌の発生率, 個数 ともに生理食塩水を早期に投与した群（3群）よりも低值を示した（10 cm基底膜あたりの膀胱癌の数 は 2 群と 3 群の間で $\mathrm{P}<0.05)$ 。以上より，BCG膀胱内注入療法はラットにおいては予防的な目的では効 果があると思われた。一方, 生理食塩水の膀胱内注入は, ラットにおいて膀胱発癌をプロシートする事 が再確認され，BCGの溶解液として一般に使用されている生理食塩水の妥当性について検討の余地があ ることが示唆された。

\section{P - 516膀胱癌における cisplatin 耐性克服に関する検討}

\author{
浜の町 ${ }^{1)}$ 、九州大 ${ }^{2)}$ 、九州大 $\cdot$ 生化 ${ }^{3)}$ \\ 小藤秀嗣 ${ }^{1)}$ 、内藤誠二 ${ }^{2)}$ 、横溝 晃 $^{3)}$ 、古賀寛史 ${ }^{2)}$ 、長谷川周二 ${ }^{23}$ \\ 山崎武成 ${ }^{2)}$ 、野間秀哉 ${ }^{2)} 、$ 熊澤淨一2)
}

【目的】我々はヒト膀胱癌培養細胞株 KK47の cisplatin 耐性株KK47/DDP10、KK47/DDP20 を樹立し細胞内 GSH の増加、細胞内 platinum 蓄積堛の減少がその耐性に関与していること を昨年の本会で報告した。今回これら耐性株の耐性克服につき検討した。

【対象と方法】ヒト膀脱癌培養細胞株 KK47、及びこれより樹立したcisplatin 而性株 KK47/DDP10、KK47/DDP20を用い、buthionine sulfoximine (BSO)、amphotericin Bによる cisplatinに対する感受性の変化を MTT assayにより検討した。また細胞内 GSH 量、細胞内 platinum 蓄積量の変化につき検討した。

【結果】KK47/DDP10、KK47/DDP20の cisplatinに対する耐性度は MTT assayによる IC50 の比較で親株 KK47に比し各々約9倍、19倍であった。KK47/DDP10、KK47/DDP20の細胞 内 GSH 量はBSO $100 \mu \mathrm{M}$ と24時間接触後親株とほほ同程度に減少し、cisplatinへの耐性度は 各々親株の約2倍、4倍にまで低下した。またamphotericin Bにより耐性株の細胞内platinum 蓄 積量は濃度依存性に有意に増加し、10 $\mathrm{g} / \mathrm{ml}$ の amphotericin B濃度下で耐性株のcisplatinに対す るIC50はamphotericin B非存在下の1/2以下に低下した。

【結論】膀胱癌の cisplatin 耐性がBSO、amphotericin Bにより克服される可能性が示唆され た。 